Jurnal Progres Ekonomi Pembangunan (JPEP)

Volume 4, Nomor 1 (2), Tahun 2019

http://ojs.uho.ac.id/index.php/JPEP

\title{
PENGARUH FASILITATOR PENDAMPING DAN KELEMBAGAAN TERHADAP TINGKAT KINERJA KEUANGAN DENGAN PENGAWASAN PEMERINTAH DAERAH SEBAGAI VARIABEL MEDIASI
}

\author{
Ayumilawarty \\ Program Pascasarjana, Universitas Halu Oleo, Kendari \\ Email: ayuindah0881@gmail.com
}

Arifuddin Mas'ud

Universitas Halu Oleo, Kendari

Husin

Universitas Halu Oleo, Kendari

\begin{abstract}
Abstrak
This study aims to find out and analyze the influence of facilitator and institutional facilitators on the level of financial performance with the supervision of local government as a mediating variable. This study is an expo facto research using the survey method. The population in this study was 64 respondents from Kelurahan Unit Management in Kendari City. The sample of this study is the entire study population which amounted to 64 financial management units.

The results of the study show that the facilitator has a positive and significant effect on financial performance. The facilitator has a negative and insignificant effect on the supervision of the local government, the institution has a positive and not significant effect on financial performance, the institution has a positive and significant effect on the supervision of the local government and supervision of the regional government positive and significant effect on financial performance. Regional government oversight is not able to act as a mediating variable on the relationship of facilitating facilitators in improving financial performance and supervision of local government capable of acting as a mediating variable on the relationship of facilitating facilitators in improving financial performance.
\end{abstract}

Keywords: Companion Facilitator, Institutional, Financial Performance, Regional Government Oversight

\section{PENDAHULUAN}

Program nasional pemberdayaan masyarakat (PNPM) Mandiri perkotaan merupakan wujud penanggulangan kemiskinan berbasis pembangunan partisipatif dan pemberdayaan masyarakat. Partisipatif dimaksudkan adalah bentuk keterlibatan masyarakat baik sebagai peneriman pinjaman maupun sebagai pelaku pengelola dana pinjaman tersebut. Sementara Pemberdayaan masyarakat melalui tiga jenis kegiatan pokok yaitu infrastruktur, siosial dan ekonomi yang dikenal dengan Tridaya.Wujud kegiatan ekonomi dengan kegiatan pinjaman bergulir, yaitu pemberian pinjaman dalam skala mikro kepada masyarakat miskin di wilayah kelurahan atau desa yang tergabung dalam kelompok swadaya masyarakat (KSM).(Suyuti, 2012).

Penganggulangan kemiskinan dilakukan dengan memberdayakan masyarakat melalui tiga jenis kegiatan pokok yaitu Infrastruktur, Sosial dan Ekonomi yang dikenal dengan Tridaya.Salah satu kegiatan dalam PNPM - MP yang dilaksanakan sejak tahun 1999 secara nasional hingga sekarang adalah pemberian pinjaman bergulir kepada masyarakat miskin melalui Kelompok Swadaya Masyarakat (KSM).Pemberian pinjaman bergulir hanya merupakan salah satu upaya meningkatkan pendapatan masyarakat miskin agar bisa terlepas dari kemiskinannya. 
Jurnal Progres Ekonomi Pembangunan (JPEP)

Volume 4, Nomor 1 (2), Tahun 2019

http://ojs.uho.ac.id/index.php/JPEP

Unit Pengelola Kegiatan (UPK) adalah suatu lembaga yang dibentuk dan berfungsi berfungsi membantu pengelolaan kegiatan termasuk menyalurkan dana bantuan masyarakat dalam PNPM Mandiri Perkotaan. UPKmemiliki peran sebagai unit pengelola dan operasionalpelaksanaan kegiatan program yang memilikistandar operasional kegiatan, standarpengelolaan program dan standar pengelolaandana perguliran. Pengurus UPK sekurang-kurangnya terdiri dari ketua, sekretaris, danbendahara serta kasir.Pengurus UPK berasaldari anggota masyarakat yang diajukan olehdesa berdasarkan hasil musyawarah desadan selanjutnya dipilih dan ditetapkan dalammusyawarah antar desa.

Arah dan tahapan penataan danpengembangan kelembagaan UPK terutamadalam mengantisipasi periode pascaprogram, antara lain; (a) UPK kedepandiarahkan menjadi pelaksana pengelolaansistem pembangunan partisipatif yang telahterintergrasi dengan pembangunan regular; (b) UPK difungsikan dalam pengelolaan danabergulir dan memperluas pelayanan bagikelompok usaha dan kelompok perempuan; (c) mendorong terjadinya proses pengakarandi masyarakat dan penguatan legalitas UPK,serta pengembangan jaringan UPK.

Keberhasilan proses pelaksanaan tahapankegiatan serta upaya pemeliharaan danpelestarian hasil-hasil kegiatan PNPM Mandiriperkotaan harus ditata sedemikian rupa denganmenempatkan UPK sebagai pelaku utama yangmemiliki legalitas dan aturan kelembagaanyang komprehenship. Untuk menjaminpelaksanaan kegiatan yang difasilitasi olehUPK dapat berjalan sebagaimana mestinya,maka secara berkesinambungan dilakukanpenataan dan penguatan kelembagaan UPK.Disamping itu, evaluasi kinerja pengurus UPKsenantiasa dilakukan dengan sistematis danberkelanjutan sehingga dicapai performa UPKyang ideal.

PNPM Mandiri Perkotaan hanya menyediakan alternatif kegiatan pinjaman bergulir, masyarakat sendirilah yang memutuskan apakah akan menggunakan kegiatan pemberian pinjaman bergulir dalam program penanggulangan kemiskinannya. Penetapan kegiatan pemberian pinjaman bergulir kepada masyarakat miskin diputuskan sendiri oleh masyarakat melalui Badan Keswadayaan Masyarakat (BKM).Pinjaman Bergulir dalam PNPM Mandiri Perkotaan bisa mencapai sasaran yang ditentukan apabila semua pelaku baik BKM, Pengawas, UPK dan KSM Peminjam telah memenuhi persyaratan dan mengikuti ketentuan yang telah ditetapkan. PNPM Mandiri Perkotaan dijadikan momen untuk tahap konsolidasi keuangan mikro. Oleh sabab itu dalam tahapan ini perlu di ciptakan UPK yang kuat, sehat dan secara operasional terpisah dari BKM. Masyarakat sendiri harus terlibat dalam keputusan menentukan masa depan UPK.

Permasalahan yang berkaitan dengan kegiatan pinjaman dana bergulir sangat dinamis dan fluktuatif. Terkadang kondisi kinerja bulan ini sudah membaik seharusnya kinerja bulan depan akan semakin baik atau meningkat, namun terkadang juga kinerja dibulan berikutnya justru menurun, hal ini karena BKM dan Perangkatnya serta masyarakat sebagai sasaran program belum sepenuhnya berdaya sebagaimana yang diharapkan sebagai tujuan program ini. Selain itu kinerja MK sangat dipengaruhi oleh berjalan tidaknya organisasi Kelembagaan BKM.

Permasalahan yang sering dihadapi dalam pelaksanaan kegiatan pinjaman dana bergulir di Kota Kendari adalah sebagai berikut :

1. Organisasi BKM dan perangkatnya banyak yang tidak berjalan optimal, sehingga berpengaruh dalam kinerja UPK di BKM.

2. Pergantian perangkat UPK dan Sekretaris BKM terkadang dilakukan dengan cara dadakan tanpa melalui proses yang sesuai dengan pedoman PNPM - MP

3. Sulitnya BKM menemukan tenaga atau personil UPK dan Sekretaris BKM yang mampu melakukan proses pembukuan sesuai yang diharapkan, selain itu sangat rendah minat masyarakat untuk jadi UPK karena tugasnya yang berat sementara insentifnya sangat minim, sehingga tenaga yang dapat 
Jurnal Progres Ekonomi Pembangunan (JPEP)

Volume 4, Nomor 1 (2), Tahun 2019

Page: 1-15

http://ojs.uho.ac.id/index.php/JPEP

direkrut oleh BKM memang terkadang dalam kondisi yang agak terpaksa

4. Hasil kinerja UPK oleh BKM belum menjadi alat indictor kinerja oleh BKM. Misalnya sangat jarang Kinerja UPK masuk dalam pembahasan rapat rutin BKM tiap bulannya

5. Faskel masih kurang melakukan analisa data kinerja UPK sehingga hanya dibuat untuk keperluan laporan saja.

Tingkat keberhasilan kegiatan ekonomi bergulir yang dikelola oleh Unit Pengelola keuangan (UPK) dipengaruhi oleh banyak aspek.Salah satu faktor yang dapat mempengaruhi kinerja UPK adalah fasilitator pendamping. Pelaksanaan kinerja UPK dibutuhkan peran fasilitator pendamping dalam upaya pengelolaan bantuan dana bergulir PNPM mandiri perkotaan. Fasilitator pendamping sebagai the man broker, idealnya memiliki kemampuan komunikasi dan teknis keuangan. Menurut Lipit, et al (1958), bahwa fasilitator pendamping sebagai agent of change harus memiliki kemampuan komunikasi pembangunan, sumber dan komunikator agar dapat mempengaruhi proses pengambilan keputusan yang dilakukan oleh calon penerima manfaat dalam kegiatan pembangunan.

Fasilitator pendamping adalah pekerja profesional sebagai pelaksana program/kegiatan demi tercapainya tujuan-tujuan komunikasi pembangunan. Berdasarkan status dan lembaga tempatnya bekerja, fasilitator dibedakan dalam tiga bagian, yakni: (1) pegawai negeri sipil; (2) fasilitator swasta; dan (3) fasilitator swadaya. Fasilitator harus mampu mengorganisasikan, memotivasi dan menggerakkan, melakukan peran bantuan dan advokasi kebijakan yang diperlukan penerima manfaatnya dan mampu menjadi jembatan penghubung antara pemerintah atau penyelenggara komunikasi pembangunan yang diwakili dengan masyarakatnya.Machmud, 2009). Sejalan dengan hal tersebut hasil penelitian terkait pengaruh fasilitator pendamning terhadap kinerja keuangan yang dilakukan oleh Hermantyo (2008) menyatakan bahwa peran fasilitator pendamping daerah berpengaruh signifikan dan positif terhadap pemberdayaan keluarga miskin di sektor pertanian.
Faktor lain yang dapat mempengaruhi kinerja UPK adalah kinerja kelembagaan dalah hal ini Badan Keswadayaan Masyarakat (BKM). Kelembagaan BKM sebagai lembaga masyarakat yang pada dasarnya merupakanwadah perjuangan warga masyarakat miskin, yang mandiri, berkelanjutan,dalam menyuarakan aspirasi serta kebutuhan mereka yang mampumempengaruhi proses pengambilan keputusan yang berkaitan dengan kebijakan publik ditingkat lokal, baik dari aspek sosial, ekonomi maupunlingkungan serta diharapkan mampu menjadi organisasi masyarakat yangberperan mengelola berbagai kehidupan masyarakat bersangkutan, khususnyapersoalan yang berkaitan dengan upaya-upaya penaggulangan kemiskinansecara berkelanjutan.

BKM sebagai penguatan organisasi masyarakat yang dimaksud, jugadititik beratkan pada upaya pengokohan peranannya sebagai motor penggerakdalam melembagakan dan membudayakan kembali nilai-nilai kemanusiaandan masyarakat sebagai nilai-nilai utama yang melandasi aktivitaspenanggulangan kemiskinan oleh masyarakat sendiri dikelurahan mereka,sehingga tidak ada lagi kelompok masyarakat yang masih terjebak dalamlingkaran kemiskinan, yang pada gilirannya antara lain diharapkan juga dapattercipta lingkungan kota dengan perumahan yang lebih layak huni di dalampermukiman yang lebih responsif dan dengan sistem sosial masyarakat yanglebih mandiri melaksanakan prinsip-prinsip pembangunan yangberkelanjutan. Salah satu pendekatan yang cukup efektif dalammenanggulangi kemiskinan yaitu melalui upaya-upaya yang dapat mendorongdan melibatkan masyarakat miskin bersama komponen masyarakat lainyauntuk bersinergi dan bekerjasama (Petunjuk teknis pelaksana BKM, $2002: 5$ ).

UPK merupakan salah satu unit yang dibentuk BKM untuk meningkatkan peran serta masyarakat dalam penanggulangan kemiskinan, komitmen dan etos kerja yang tinggi dari personil BKM sangat berpengaruh terhadap keberhasilan kegiatan ekonomi bergulir. Sejalan 
Jurnal Progres Ekonomi Pembangunan (JPEP)

Volume 4, Nomor 1 (2), Tahun 2019

Page: $1-15$

e-ISSN: 2052-5171

http://ojs.uho.ac.id/index.php/JPEP

dengan hal tersebut penelitian terkait pengaruh kelembagaan terahdap kinerja keuangan dilakukan oleh Gunawan (2009) yang menyatakan bahwa kelembagaan berpengaruh signifikan dan positif terhadap kinerja keuangan lembaga pengkreditan desa di Bali.

Selain fasilitator pendamping dan kelembagaan, faktor pengawasan pemerintah daerah dapat mempengaruhi kinerja keuangan UPK PNPM Mandiri Perkotaan.Secara umum peran pemerintah daerah setempat adalah memberikan dukungan dan jaminan agar pelaksaan PNPM diwilayah kerjanya dapat berjalan dengan lancar sesuai dengan aturan yang berlaku sehingga tujuan yang diharapkan melalui PNPM Mandiri Perkotaan dapat tercapai dengan baik (Pedoman PNPM, 2010:58). Sejalan dengan hal tersebut hasil penelitian terkait pengawasan pemerintah daerah terahadap kinerja UPK dilakukan oleh Kasim (2012) menyatakan bahwa pengawasan pemerintah melalui motivasi, kemampuan dan komitmen berpengaruh positif dan signifikan terhadap kinerja pengurus UPK PNPM Mandiri Perdesaan di Kabupaten Lumajang.

Berdasarkan pendapat di atas, maka dapat disimpulkan bahwa peran fasilitator pendamping dan kelembagaan dan pengawasan pemerintah daerah, maka dapat menyukseskan penanggulangan kemiskinan.Dengan demikian, maka secara langsung dapat meningkatkan kinerja keuangan tersebut.Dari awal terbentuknya PNPM Mandiri perkotaan belumdiketahui kinerja Unit Pengelola Keuangan dalam pengelolaan pinjamanbergulir khususnya kinerja program yang dilihat dari tahapperencanaan hingga dampak kegiatan bagi masyarakat.Penilaian kinerjasangat di perlukan untuk mengetahui keberhasilan dari pelaksanaankegiatan.Dengan mengetahui kinerja UPK dapat diketahuikeberhasilan pelaksanaan kegiatan, hambatan, dan manfaatnya bagimasyarakat sehingga dapat menjadi pertimbangan dalam mengambilkebijakan.

Tujuan yang hendak dicapai dalam penelitian ini adalah untuk menguji dan menganalisis pengaruh fasilitator pendamping dan kelembagaan terhadap tingkat kinerja keuangan dengan pengawasan pemerintah daerah sebagai variabel mediasi.Berdasarkan uraian di atas, maka hipotesis dalam penelitian iniadalah sebagai berikut:

1. H1 : Ada pengaruh positif dan signifikan fasilitator pendamping terhadap kinerja keuangan UPK PNPM mandiri Kota Kendari

2. H2 : Ada pengaruh positif dan signifikan fasilitator pendamping terhadap pengawasan pemerintah daerah

3. H3 : Ada pengaruh positif dan signifikan kelembagaan terhadap kinerja keuangan UPK PNPM Mandiri Kota Kendari.

4. H4 : Ada pengaruh positif dan signifikan kelembagaan terhadap pengawasan pemerintah daerah.

5. H5 : Ada pengaruh positif dan signifikan pemerintah daerah terhadap kinerja keuangan UPK PNPM Mandiri Kota Kendari.

6. H6 : Pengawasan pemerintah daerah berperan sebagai mediasi pengearuh antara fasilitator pendamnping dengan kinerja keuangan UPK PNPM Mandiri Kota Kendari

7. H7 : Pengawasan pemerintah daerah berperan sebagai mediasi pengearuh antara kelembagaan dengan kinerja keuangan UPK PNPM Mandiri Kota Kendari.

\section{TINJAUAN PUSTAKA}

\section{Fasilitator Pendamping}

Fasilitator Pendamping adalah seorang yang telah mendapatkan pelatihan khusus yang diselenggarakan oleh Bappenas dan telah lulus sebagai fasilitator pendamping (Bappenas, 2012). fasilitator pendamping adalah orang yang memiliki kemampuan memfasilitasi dan mendampingi badan keswadayaan masyarakat, unit pelaksana keuangan dan kelompok swadaya masyarakat serta pengawasan pemerintah daerah terkait apa dan bagaimana tata cara pengelolaan dana bergulir PNPM Mandiri perkotaan. 
Jurnal Progres Ekonomi Pembangunan (JPEP)

Volume 4, Nomor 1 (2), Tahun 2019

Page: $1-15$

http://ojs.uho.ac.id/index.php/JPEP

\section{Kelembagaan}

Kelembagaan adalah suatu hubungan dan tatanan antara anggota masyarakat atau organisasi yang melekat, di wadahi dalam suatu jaringan atau organisasi, yang dapat menentukan suatu hubungan antara manusia atau organisasi dengan ditentukan oleh faktor-faktor pembatas dan pengikat brupa norma, kode etik atau aturan formal dan non-formal untuk berkerjasama demi mencapai tujuan yang diinginkan, menurut bulkis, kelembagaan berarti seperangkat peraturan yang mengatur tingakah laku masyarakat untuk mendapatkan tujuan hidup mereka. Kelembagaan berisi sekelompok orang yang bekerjasama dengan pembagian tugas tertentu untuk mencapai suatu tujuan yang diinginkan.Tujuan peserta kelempok dapat berebeda, tetapi dalam organisasi menjadi satu kesatuan.Kelembagaan lebih ditekankan pada aturan main (the rules) dan kegiatan kolektif (collective action) untuk mewujudkan kepentingan umum atau bersama.Kelembagaan menurut beberapa ahli, sebagian dilihat dari kode etik dan aturan main.Sedangkan sebagian lagi dilihat pada organisasi dengan struktur, fungsi dan menejemennya.

\section{Pengawasan Pemerrintah Daerah}

Menurut Mardiasmo (2002) keberhasilan pelaksanaan otonomi daerah tidak terlepas dari dukungan tiga aspek berikut yaitu pengawasan, pengendalian,dan pemeriksaan. Ketiga hal tersebut pada dasarnya berbeda baik konsepsimaupun aplikasinya.Pengawasan mengacu pada tindakan atau kegiatan yangdilakukan oleh pihak di luar eksekutif (yaitu masyarakat dan DPRD) untuk mengawasi kinerja pemerintahan.Pengendalian (control) adalah mekanisme yangdilakukan eksekutif (pemerintah daerah) untuk menjamin dilaksanakannya sistemdan kebijakan manajemen sehingga tujuan organisasi dapat tercapai.Pemeriksaan(audit) merupakan kegiatan yang dilakukan oleh pihak yang memiliki independensi dan memiliki kompetensi profesional untuk memeriksa apakah hasil kinerja pemerintah daerah telah sesuai dengan standar atau kinerja yang ada. Pada tataran teknis-aplikatif juga berbeda, monitoring oleh DPRD dilakukan pada tahap awal.

\section{Kinerja Keuangan}

Kinerja keuangan merupakan gambaran kondisi keuangan perusahaan pada suatu periode tertentu menyangkut aspek penghimpunan dana maupun penyaluran dana, yang biasanya diukur dengan indikator kecukupan modal, likuiditas, dan profitabilitas (Jumingan, 2006).

\section{METODE PENELITIAN}

\section{Jenis Penelitian}

Berdasarkan metode, penelitian ini menggunakan jenis penelitian "Metode Eksplanansi Ilmu", yakni bagian dari jenis penelitian eksplanatori yang bertujuan mengembangkan teori dengan cara menguji hipotesis (hypothesis Testing Research). (Ferdinand, 2006)

Ruang Lingkup dan Objek Penelitian

Penelitian ini menganalisis pengaruh fasilitator pendamping dan kelembagaan terhadap kinerja keuangan PNPM Mandiri Unit Pengelola Keuangan Kota Kendari dengan pemerintah daerah sebagai variabel mediasi. Objek penelitian ini adalah kantor Unit Pengelola Keuangan yang tersebar di seluruh kelurahan Kota Kendari.

\section{Defenisi Operasional Variabel}

1. Fasilitator pendamping (X1), adalah fasilitator yang bertugas di kecamatan dan kelurahan yang merupakan pendamping masyarakat yang berperan memfasilitasi masyarakat dalam setiap proses tahapan, mulai dari sosialisasi, perencanaan, pelaksanaan dan pelestarian serta membimbing KPMD atau pelaku-pelaku lainnya di desa/kelurahan dan kecamatan. (PNPM Mandiri Perkotaan : 2013). Variable falitator pendamping meliputi : (1) visioner; (2) pembimbingan; (3) afiliatif; dan (4) demokratis.

2. Kelembagaan (X2), adalah institusi atau kelembagaan adalah aturan-aturan (constraints) yang diciptakan oleh manusia untuk mengatur dan membentuk interaksi politik, sosial dan ekonomi. Variabel kelembagaan meliputi : (1) BKM, terdirii: (a) produktifitas pengurus, (b) kualitas layanan pengurus, (c) responsivitas pengurus, (d) responsibilitas pengurus, dan 
Jurnal Progres Ekonomi Pembangunan (JPEP)

Volume 4, Nomor 1 (2), Tahun 2019

Page: $1-15$

http://ojs.uho.ac.id/index.php/JPEP

akuntabilitas pengurus; dan (2) KSM, terdiri dari : (a) keorganisasian, dan (b) administrasi.

3. Pengawasan Pemerintah Daerah (Y1), adalah upaya agar sesuatu dilaksanakan sesuai dengan peraturan yang telah ditetapkan dan instruksi yang telah dikeluarkan" "Sondang Siagian, Pengawasan adalah proses pengamatan pelaksanaan seluruh kegiatan organisasi untuk menjamin agar semua pekerjaan yang dilaksanakan sesuai dengan rencana yang telah ditentukan sebelumnya (Lyndal F. Urwick, dalam Tjandra, 2006). Variabel pengawasan pemerintah daerah meliputi : (1) objektif dan professional; (2) transparan; (3) Akuntabel; (4) partisipatif; (5) orientasi solusi; (6) integratif; dan (7) berbasisi kinerja.

4. Kinerja Keuangan (Y2), adalah penilaian kondisi keuangan yang menjadi prestasi perusahaan yang memerlukan analisis dengan beberapa tolak ukur seperti rasio dan indeks sehingga dua data keuangan bisa terhubung antara satu dengan yang lain (sawir, 2005 dalam dosen akuntansi.com, 2018). Variable kinerja keuangan meliputi : (1) Current Ratio; (2) Quict Ratio; (3) Return of Asset; (4) Return of Equipt; dan (5) Net Profit Margin

Lokasi Penelitian

Penelitian ini dilaksanakan di PNPM Mandiri Kota Kendari.Adapun yang menjadi sasaran penelitian di PNPM Mandiri Kota Kendari adalah unit pengelola keuangan (UPK).

Populasi dan Sampel Penelitian

Populasi pada penelitian ini sebanyak 64 unit pengelola keuangan (UPK) yang terdapat pada sebelas kecamatan di Kota Kendari.Ukuran sampel dalam penelitian ini menggunakan ukuran yang disarankan Roscoe (dalam Sekaran, 2006), bahwa ukuran populasi tidak mencapai seratus maka keseluruhan populasi digunakan menjadi sampel penelitian.Dengan demikian sampel penelitian ini adalah keseluruhan populasi penelitian yang berjumlah 64 unit pengelola kegiatan (UPK).

Instrumen Penelitian

Instrumen penelitian yang digunakan untuk mengumpulkan data adalah angket atau kuesioner yang diberikan kepada pengurus UPK se-Kota Kendari sebagai responden penelitian.

Teknik Pengumpulan Data

Teknik pengumpulan data dalam penelitian ini terdiri dari; angket yaitu pengumpulan data dengan cara mengedarkan kuisioner tertutup dan terstruktur kepada responden terpilih di Kota Kendari, Wawancara, yaitu melakukan tanya jawab langsung dengan responden terpilih di Kota kendari, dengan harapan mendapatkan informasi tambahan buat kelengkapan data yang diperoleh melalui kuesionerdan Dokumentasi yaitu pengumpulan data dengan cara mencatat atau mengkopi dokumen yang telah dipublikasikan oleh PNPM Mandiri Perkotaan maupun P2KP kecamatan dan kelurahan.

Teknik Analisis Data

a. Uji Validitas dan Reliabilitas

b. Analisis Deskripsi Variabel

c. Uji Normalitas

d. Uji Multikolonieritas

e. Uji Heterosdasitas

f. Auji Autikorelasi

g. Analisis Faktor

h. Uji Hipotesis

\section{HASIL DAN PEMBAHASAN}

Uji Koefisien Jalur Pengaruh Parsial (Uji t) atau Langsung

Uji $t$ pada dasarnya digunakan untuk menunjukkan seberapa jauh pengaruh satu variabel penjelas/ independen secara individual dalam menerangkan variasi variabel dependen. Pengujian dilakukan dengan melihat taraf signifikansi (p-value), jika taraf signifikansi yang dihasilkan dari perhitungan dibawah 0,05 maka hipotesis diterima dan sebaliknya jika taraf signifikansi lebih besar dari 0,05 maka hipotesis ditolak. Hasil uji koefisien jalur pengaruh parsial atau langsung dapat dilihat pada Tabel 1.

Berdasarkan data pada Tabel 1 diperoleh beberapa kesimpulan.

1. Fasilitator pendamping berpengaruh positif dan signifikan terhadap pengawasan pemerintah daerah.

Pengujian hipotesis dengan persamaan regresi menghasilkan koefisien jalur pengaruh langsung fasilitator pendamping terhadap pengawasan pemnerintah daerah dengan nilai $-0,045$ dengan

Corresponding Author: Ayumilarwaty | 6 
Jurnal Progres Ekonomi Pembangunan (JPEP)

Volume 4, Nomor 1 (2), Tahun 2019

Page: $1-15$

e-ISSN: 2052-5171

http://ojs.uho.ac.id/index.php/JPEP

t-sig sebesar 0,734. Hubungan ini dapat diartikan bahwa fasilitator pendamping berpengaruh negatif $(-0,045)$ dan tingkat signifikan $t$ (t-sig) sebesar $0,734>0,05$ terhadap pengawasan pemnerintah daerah. Mengingat koefisien jalur bertanda negatif dan signifikan dapat disimpulkan bahwa hubungan antara keduanya adalah tidak searah, artinya fasiiltator pendamping belum memberikan peningkatan pengawasan pemerintah daerah.

Tabel 1

Koefisien Jalur dan Pengujian Hipotesis Pengaruh Parsial

\begin{tabular}{|c|ll|c|c|c|c|}
\hline \multicolumn{2}{|c|}{ Pengaruh langsung antara variabel } & Koef. Jalur & t- statistik & Sig.t & Hasil \\
\hline H1 & $\begin{array}{l}\text { Fasilitator } \\
\text { pendamping }\end{array}$ & $\begin{array}{l}\text { Pengawasan } \\
\text { Pemerintah } \\
\text { Daerah }\end{array}$ & $-0,045$ & $-0,342$ & 0,086 & Ditolak \\
\hline H2 & $\begin{array}{l}\text { Fasilitator } \\
\text { pendamping }\end{array}$ & $\begin{array}{l}\text { Kinerja } \\
\text { Keuangan }\end{array}$ & 0,327 & 3,076 & 0.003 & Diterima \\
\hline H3 & Kelembagaan & $\begin{array}{l}\text { Pengawasan } \\
\text { Pemerintah } \\
\text { Daerah }\end{array}$ & 0,435 & 3,275 & 0.002 & Diterima \\
\hline H4 & Kelembagaan & $\begin{array}{l}\text { Kinerja } \\
\text { Keuangan }\end{array}$ & 0.199 & 1.026 & 0.309 & Ditolak \\
\hline H5 & $\begin{array}{l}\text { Pengawasan } \\
\text { Pemerintah } \\
\text { Daerah }\end{array}$ & $\rightarrow \begin{array}{l}\text { Kinerja } \\
\text { Keuangan }\end{array}$ & 0,483 & 4,611 & 0,000 & Diterima \\
\hline
\end{tabular}

Sumber: Hasil Output IBM SPSS 21, Data Olahan 2018

2. Fasilitator pendamping berpengaruh positif dan signifikan terhadap kinerja keuangan.

Pengujian hipotesis dengan persamaan regresi menghasilkan koefisien jalur pengaruh langsung fasilitator pendamping terhadap kinerja keruangan dengan nilai $-0,327$ dengan $t$-sig sebesar 0,003. Hubungan ini dapat diartikan bahwa fasilitator pendamping berpengaruh positif $(0,327)$ dan tingkat signifikan $\mathrm{t}(\mathrm{t}-\mathrm{sig})$ sebesar $0,003<0,05$ terhadap kinerja keuangan. Mengingat koefisien jalur bertanda positif dan signifikan dapat disimpulkan bahwa hubungan antara keduanya adalah searah, artinya semakin tinggi kualitas fasiltator pendamping maka akan meningkatkan kinerja keuangan UPK-PNPM Mandiri Perkotaan.

3. Kelembagaan berpengaruh positif dan signifikan terhadap pengawasan pemerintah daerah.

Pengujian hipotesis dengan persamaan regresi menghasilkan koefisien jalur pengaruh langsung kelembagaan terhadap pengawasan pemerintah daerah.dengan nilai 0,435 dengan t-sig sebesar
0,002. Hubungan ini dapat diartikan bahwa kelembagaan berpengaruh positif $(0,435)$ dan tingkat signifikan $t(t-s i g)$ sebesar 0,002 $<0,05$ terhadap pengawasan pemerintah daerah.. Mengingat koefisien jalur bertanda positif dan signifikan dapat disimpulkan bahwa hubungan antara keduanya adalah searah, artinya semakin berkualitas kelembagaan maka semakin meningkat pengawasan pemnerintah daerah.

4. Kelembagaan berpengaruh positif dan signifikan terhadap kinerja keuangan.

Pengujian hipotesis dengan persamaan regresi menghasilkan koefisien jalur pengaruh langsung kelembagaan terhadap kinerja keuangan dengan nilai 0,199 dengan t-sig sebesar 0,309. Hubungan ini dapat diartikan bahwa kelembagaan berpengaruh positif $(0,199)$ dan tingkat signifikan t (t-sig) sebesar 0,309 >0,05 terhadap kinerja keuangan. Mengingat koefisien jalur bertanda positif dan tidak signifikan dapat disimpulkan bahwa hubungan antara keduanya adalah searah namun tidak bernmanfaat, artinya kelembagaan belum memberikan manfaat dalam 
Jurnal Progres Ekonomi Pembangunan (JPEP)

Volume 4, Nomor 1 (2), Tahun 2019

Page: $1-15$

e-ISSN: 2052-5171

http://ojs.uho.ac.id/index.php/JPEP

meningkatkan kinerja keuangan UPK-PNPM Mandiri Perkotaan.

5. Pengawasan pemerintah daerah berpengaruh positif dan signifikan terhadap kinerja keuangan.

Pengujian hipotesis dengan persamaan regresi menghasilkan koefisien jalur pengaruh langsung pengawasan pemerintah daerah terhadap kinerja keuangan dengan nilai 0,483 dengan t-sig sebesar 0,000 . Hubungan ini dapat diartikan bahwa pengawasan pemerintah daerah berpengaruh positif $(0,483)$ dan tingkat signifikan $\mathrm{t}$ ( $\mathrm{t}$-sig) sebesar $0,000<0,05$ terhadap kinerja keuangan. Mengingat koefisien jalur bertanda positif dan signifikan dapat disimpulkan bahwa hubungan antara keduanya adalah searah, artinya semakin tinggki kualitas pengawasan pemerintah daerah maka kinerja keuangan UPK-PNPM Mandiri Perkotaan semakin meningkat.

\section{Uji Koefisien Jalur Pengaruh Tidak Langsung (Mediasi)}

Pengujian pengaruh mediasi bertujuan untuk mendeteksi kedudukan variabel intervening dalam model. Pengujian mediasi dilakukan guna menentukan sifat hubungan antara variabel baik sebagai variabel mediasi sempurna, mediasi parsial dan bukan variabel mediasi. Pendekatan perbedaan koefisien menggunakan metode pemeriksaan dengan melakukan analisis tanpa melibatkan variabel mediasi dan rumus sobel, hasil pengujian variabel mediasi dapat dilhat pada Tabel 2.

Tabel 2

Koefisien Jalur dan Pengujian Hipotesis Pengaruh Mediasi

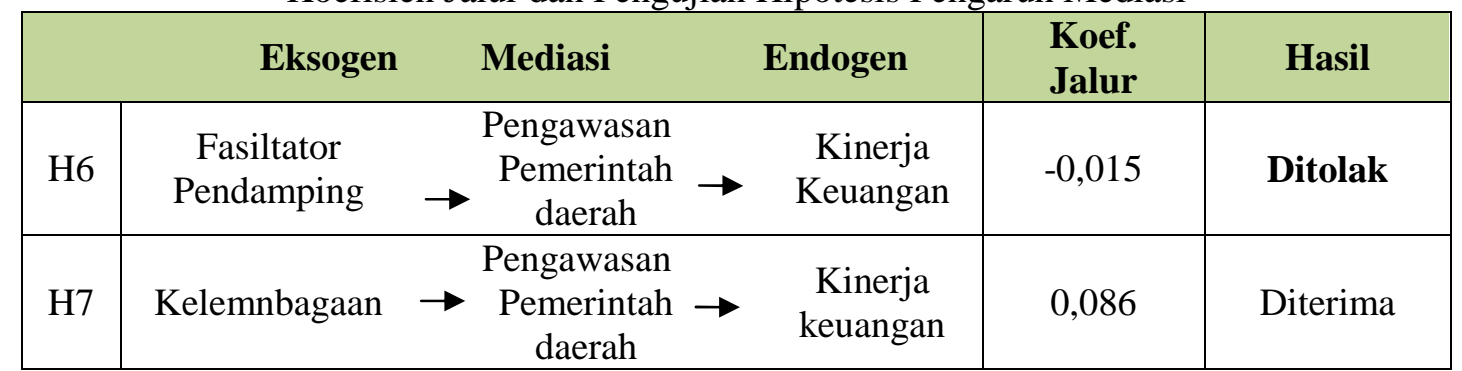

Sumber: Hasil Output IBM SPSS 21, Data Olahan 2018

Berdasarkan data pada Tabel 2, Hasil perhitungan Sobel diperoleh Jika z-value diperoleh beberapa kesimpulan.

1. Pengawasan pemerintah daerahberperan sebagai mediasi pengaruh antara fasilitator pendamping dengan kinerja keuangan

Hasil evaluasi pengujian pengaruh variabel fasilitator pendamping terhadap kinerja keuangan pada model awal dengan melibatkan variabel mediasi, menunjukkan fasilitator pendamping secara langsung tidak berpengaruh signifikan terhadap pengawasan pemerintah daerahdan secara langsung berpengaruh signifikan terhadapkinerja keuangan, diperoleh nilai estimasi koefisien jalur pengaruh tidak langsung sebesar -0,015hasil ini diperoleh dari perkalian koefisien jalur $(-0,045 \times 0,327=-0,015)$.. Agar menyimpulkan sifat mediasi pengawasan pemerintah daerah, maka analisis dibuktikan dengan menggunakan rumus Sobel.

sebesar -0,3906 dibanding dengan harga mutlak $\leq 1,96$ atau tingkat signifikansi statistik $\mathrm{z}$ (pvalue) $>\alpha=0,05$, berarti indirect effect atau pengaruh mediasi variabel fasilitator pendamping terhadapkinerja keuanganmelalui mediasi variabel pengawasan pemerintah daerah tidak signifikan. Dapat disimpulkan dengan pendekatan pengujian mediasi dengan rumus Sobel bahwa fasilitator pendamping berpengaruh signifikan secara langsungterhadap kinerja keuangan, namun fasilitator pendamping tidak berpengaruh signifikan melalui peran mediasi pengawasan pemerintah daerah.

2. Pengawasan pemerintah daerahberperan sebagai mediasi pengaruh antara kelembagaan dengan kinerja keuangan

Hasil evaluasi pengujian pengaruh variabel kelembagaan terhadap kinerja keuangan pada model awal dengan melibatkan variabel mediasi, 
http://ojs.uho.ac.id/index.php/JPEP

menunjukkan kelembagaan secara langsung berpengaruh signifikan terhadap pengawasan pemerintah daerahdan secara langsung tidak berpengaruh signifikan terhadapkinerja keuangan, diperoleh nilai estimasi koefisien jalur pengaruh tidak langsung sebesar 0,086hasil ini diperoleh dari perkalian koefisien jalur $(0,435 \mathrm{x}$ $0,199=0,086)$. Agar menyimpulkan sifat mediasi pengawasan pemerintah daerah, maka analisis dibuktikan dengan menggunakan rumus Sobel.

Hasil perhitungan Sobel diperoleh Jika z-value sebesar 7,825 dibanding dengan harga mutlak $\geq$ 1,96 atau tingkat signifikansi statistik $\mathrm{z}$ (pvalue) $<\alpha=0,05$, berarti indirect effect atau pengaruh mediasi variabel kelembagaan terhadapkinerja keuanganmelalui mediasi variabel pengawasan pemerintah daerah signifikan. Dapat disimpulkan dengan pendekatan pengujian mediasi dengan rumus Sobel bahwa kelembagaan tidak berpengaruh signifikan secara langsungterhadap kinerja keuangan, namun kelembagaan berpengaruh signifikan terhadap kinerja keuangan melalui peran mediasi pengawasan pemerintah daerah.

Rangkuman analisis regresi koefisien jalur pengaruh fasiltator pendamping (X1) dan kelembagaan (X2) terhadap tingkat kinerja keuangan (Y2) dengan variabel pengawasan pemerintah daerah (Y1) sebagai variabel mediasi digambarkan sebagai berikut.

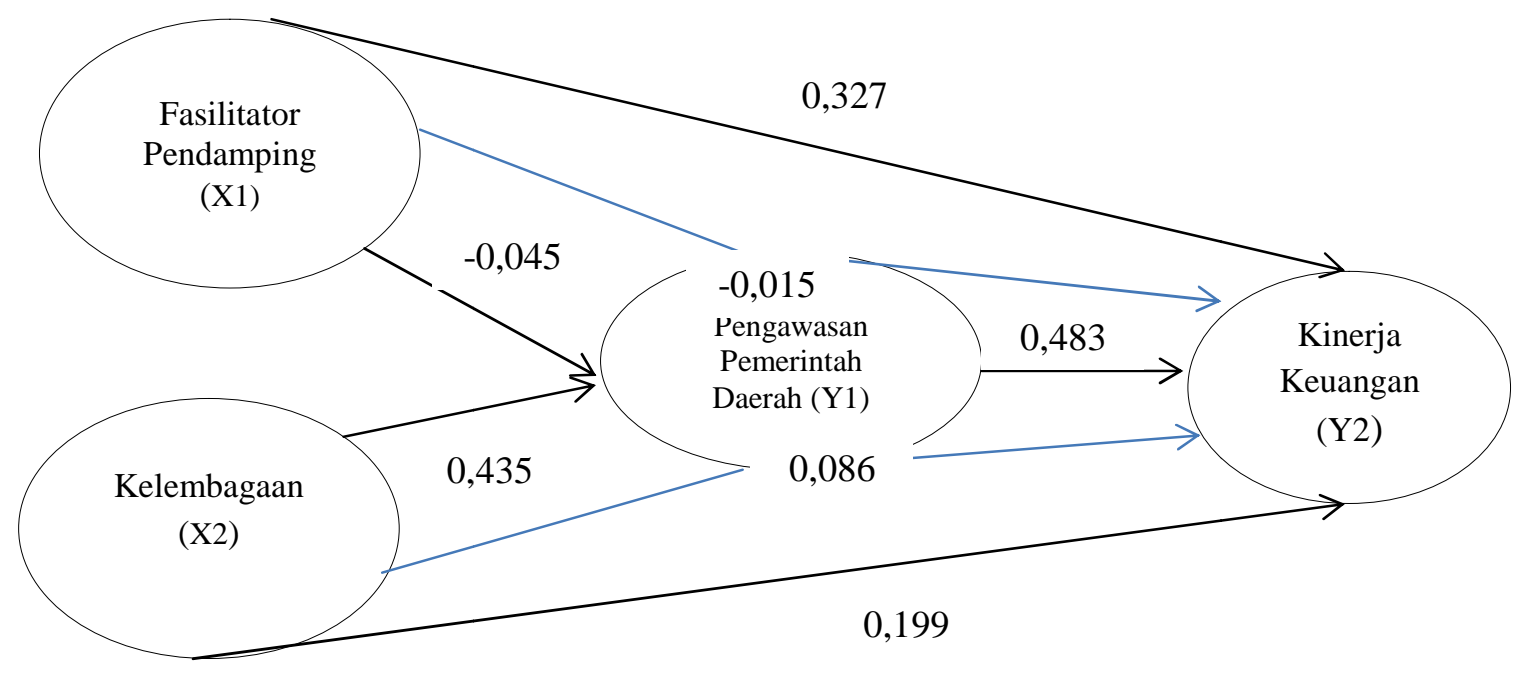

Gambar 1 Rangkuman Analisis Koefisien Jalur

\section{Pembahasan Hasil Penelitian}

\section{Pengaruh Fasilitator Pendamping} terhadap Pengawasan Pemerintah Daerah Hasil analisis menunjukkan bahwa fasilitator pendamping berpengaruh negatif dan tidak signifikan terhadap pengawasan pemerintah daerah.Hal ini menunjukkan bahwa fasilitator pendamping tidak berpengaruh terhadap pengawasan pemerintah daerah.Koefisien jalur bertanda negatif dan tidak signifikan berarti tidak ada hubungan searah antara fasilitator pendamping dan pengawasan pemerintah daerah.Hal ini disebabkan karena fasilitator pendamping dan pihak pemerintah daerah dalam hal aparat kelurahan tidak menjalin kerjasama yang baik dalam hal melakukan pengawasan ataupun pendampingan terhadap masyarakat.

Fungsi pemerintah dalam kaitannya dengan pemberdayaan yaitu mengarahkan kemandirian masyarakat dan melaksanakan pembangunan demi terciptanya kemakmuran, tidak serta merta dibebankan masyarakat.Perlu adanya peran pemerintah yang secara optimal dan mendalam untuk membangun masyarakat, maka peran pemerintah sebagai fasilitator yaitu menciptakan 
Jurnal Progres Ekonomi Pembangunan (JPEP)

Volume 4, Nomor 1 (2), Tahun 2019

Page: $1-15$

http://ojs.uho.ac.id/index.php/JPEP

kondisi yang kondusif bagi pelaksanaan pembangunan daerah. Sebagai fasilitator, pemerintah bergerak di bidang pendampingan melalui pelatihan, pendidikan dan peningkatan, pendidikan dan peningkatan keterampilan serta dibidang pendanaan atu pemodalan kepada masyarakat yang diberdayakan

Pemerintah daerah seharusnya mampu menkoordinasikan pendampingan diwilayah kerjanya karena pendampingan terhadap masyarakat juga merupakan tugas dari pemrintah daerah dalam hal ini kelurahan. Idealnya pemerintah daerah dalam hal kelurahan harus dapat memposisikan dirinya juga sebagai fasilitator, namun fakta dilapangan menunjukkan bahwa aparat kelurahan melimpahkan seluruh tugas pendampingan kepada fasilitator lapangan yang seharusnya faslitator lapangan dan dibantu oleh aparat pemerintah dapat bersama-sama melakukan pendampingan kepada masyarakat miskin di Kota Kendari agar tujuan dari program pemerintah dalam memberdayakan masyarakat miskin dapat tercapai. Hal ini berbeda dengan pernyataan yang disampaikan oleh Ardian (2012) yang menyatakan bahwa fasiltator dan pemerintah memiliki hubungan searah.Dalam hal ini, hubungan yang dimaksud adalah membangun jaringan kerja.Fasilitasi yang dilakukan oleh pendamping dikalangan pemerintah harus menyentuh aspek penguatan jaringan dari tingkat institusi nasional hingga masyarakat.Penguatan jaringan sangat penting dalam membangun kebersamaan, keberlanjutan dan kesiapan masyarakat mengantisipasi perubahan.Jaringan yang dibangun harus mengacu pada optimalisasi program, dimana keterlibatan pemerintah berjalan secara sinergis.

\section{Pengaruh Fasilitator Pendamping terhadap Kinerja Keuangan}

Hasil analisis menunjukkan bahwa fasilitator pendamping berpengaruh positif dan signifikan terhadap kinerja keuangan.Hal ini menunjukkan bahwa fasilitator pendamping berpengaruh terhadap kinerja keuangan.Koefisien jalur bertanda positif dan signifikan berarti ada hubungan searah antara fasilitator pendamping dan kinerja keuangan. Oleh karena itu, maka dapat dijelaskan bahwa fasilitator yang memiliki visioner, pembimbingan yang baik, afiliatif dan demokratis akan memicu meningkatnya kinerja keuangan UPK PNPM Mandiri Kota Kendari. Salah satu faktor meningkatnya kinerja keuangan UPK adalah nmelakukan sosialisasi langsung secara informal kepada masyarakat.Komunikasi langsung secara informal yang dimaksud adalah fasiltator pendamping melakukan obrolan santai dengan masyarakat terutama kaum perempuan yang dilakukan di warung-warung, dan rumah penduduk yang biasanya dipake tempat berkumpul masyarakat setempat.

Pendekatan secara langsung atau jemput bola oleh tenaga fasiltator pendamping juga sangat efektif sebagai salah satu cara melakukan pembinaan kepada kelompok masyarakat peminjam, sehingga kesadaran mereka untuk mengangsur pinjaman semakin tinggi. Hasil penelitian ini sejalan dengan penelitian yang dilakukan oleh Imila (2014) yang melaporkan bahwa variabel fasilitator lapangan secara parsial memiliki pengaruh yang signifikan terhadap Return of Asset (RoA) pada lembaga keuangan mikro.Variabel Fasilitator pendamping mempunyai pengaruh positif terhadap kinerja keuangan karenadilihat dari banyaknya fasilitator pada tiapkecamatan untuk mendampingi berjalannya kegiatan.Pada tiapkecamatan kurang lebih ada 5 fasilitatordi tiap kecamatan dilihat dari banyaknyamasyarakat yang mengikuti.Jadi, semakinbanyak fasilitator maka semakin meningkat kinerja keuangan UPK.

Pengaruh fasilitator pendamping terhadap kinerja keuangan melalui pengawasan pemerintah daerah adalah sebesar $(-0,015)$ yang menunjukkan bahwa pengawasan penmerintah daerah sebagai variabel mediasi berpengaruh negaif dan tidak signifikan antara fasilitator pendamping terhadap kinerja keuangan UPK PNPM Mandiri Kota Kendari atau dapat dikatakan bahwa pengawasan pemerintah daerah tidak mampu bertindak sebagai variabel mediasi terhadap hubungan fasilitator pendamping dalam meningkatkan kinerja keuangan UPK PNPM Mandiri Kota Kendari.

Berdasarkan hasil wawancara terhadap responden UPK di Kota Kendari, selama ini 
Jurnal Progres Ekonomi Pembangunan (JPEP)

Volume 4, Nomor 1 (2), Tahun 2019

http://ojs.uho.ac.id/index.php/JPEP

fasilitator masih sangat mengatur kinerja UPK sesuai pedoman yang dibuat oleh pemerintah misalnya bantuan dana bergulir tanpa agunan, keinginan UPK sebagai pengelola harusnya ada agunan bagi peminjam karena belajar dari kelurahan lain atau sebelumnya adanya banyak tunggakan dengan berbagai alasan, saat jatuh tempo dan menunggak tidak ada barang jaminan untuk tebusan hanya mengandalkan tanggung renteng seperti tabungan KSM. Selain itu ada keinginan UPK untuk tambah dana dari Bank/pihak lain yang akan dikelolah di UPK dengan hanya membagi laba tetapi tidak diijinkan oleh pendamping kecuali tambah dana itu menjadi milik UPK seutuhnya dalam artian dihibahkan sepenuhnya menjadi dana abadi masyarakat yang dikelolah UPK tersebut.

\section{Pengaruh Kelembagaan terhadap \\ Pengawasan Pemerintah Daerah}

Hasil analisis menunjukkan bahwa kelembagaan berpengaruh positif dan signifikan terhadap pengawasan pemerintah daerah.Hal ini menunjukkan bahwa kelembagaan berpengaruh terhadap pengawasan pemerintah daerah.Koefisien jalur bertanda positif dan signifikan berarti ada hubungan searah antara kelembagaan dan pengawasan pemerintah daerah.Oleh karena itu dapat dijelaskan bahwa semakin tinggi kualitas kelembagaan maka pengawasan pemerintah daerah semakin meningkat. Hal ini sejalan dengan penelitian yang dilakukan oleh Arifani (2009) yang menyatakan bahwa kelembagaan dalam hal ini BKM sebagai motor pengerak dan fasilitator yang ditunjuk langsung oleh pemerintah untuk mensukseskan program pemerintah di daerah.

Dalam buku pedoman teknis tinjauan partisipatif, PNPM perkotaan (2007: 2) BKM dibentuk sebagai lembaga pimpinan kolektif sebagai motor penggerak penumbuhan kembali capital social seperti antara lain solidaritas, kesatuan, gotong royong dan sebagainya. Dalam upaya menanggulangi kemiskinan secara mandiridan berkelanjutan dalam menjalankan peran tersebut, BKM mengorganisasikan warga untuk merumuskan program jangka menengah tiga tahun dan rencana tahunan penanggulangan kemiskinan.
Upaya peningkatan ekonomi yang dilakukan oleh kelompok BKM yaitu memberikan pinjaman dana bergulir. Tujuan ari kegiatan ini yaitu menjadi masyarakat yang produktif sehingga mereka mampu dalam pemenuhan kebutuhan ekonomi.Dana bergulir ini digunakan untuk mendirikan usaha baru maupun mengembangkan usaha yang sudah ada.

Penunjukkan lembaga BKM oleh pemerintah sudah melalui penilaian dan pertimbangan yang matang untuk kemudian dapat menjalankan proyek pemerintah. Artinya bahwa semakin baik kualitas penilaian pemerintah maka kualitas kelembagaan yang ditunjukpun akan semakin baik. Kelembagaan dalam hal ini BKM dan aparat pemerintah dalam hal ini kelurahan merupakan dua pilar penting pembedayaan masyarakat dalam manggulangi kemiskinan.Diperlukan kerjasama yang baik anatara kelembagaan dan pemerintah daerah untuk menjalankan tugas pemerintah dalam penanggulangan kemiskinan.

\section{Pengaruh Kelembagaan terhadap Kinerja Keuangan}

Hasil analisis menunjukkan bahwa kelembagaan berpengaruh positif dan tidak signifikan terhadap kinerja keuangan.Hal ini menunjukkan bahwa kelembagaan tidak berpengaruh terhadap kinerja keuangan.Koefisien jalur bertanda positif dan tidak signifikan berarti ada hubungan searah namun tidak bermanfaat antara kelembagaan dan kinerja keuangan.Oleh karena itu, maka dapat dijelaskan bahwa kinerja kelembagaan dalam hal ini BKM belum memberikan manfaat dalam meningkatkan kinerja keuangan UPK PNPM Mandiri Kota Kendari.

Peran Kelembagaan dinilai masih kurang maksimal karena kondisi dana banyak yang macet, data nama-nama penunggak tidak ada tetapi BKM menuntut UPK untuk penagihan dana macet dengan menyelamatkan pinjaman bermasalah dan pencairan dana mengendap direkening UPK yang jumlahnya sangat sedikit karena desakan dari pihak program ataupun dari konsultan pendamping untuk melakukan penagihan, sehingga menimbulkan sedikit persoalan di masyarakat dalam hal ini KSM calon peminjam dana bergulir karena tidak 
Jurnal Progres Ekonomi Pembangunan (JPEP)

Volume 4, Nomor 1 (2), Tahun 2019

Page: $1-15$

e-ISSN: 2052-5171

http://ojs.uho.ac.id/index.php/JPEP

semua kebagian mendapatkan pinjaman dana bergulir disebabkan dana terbatas. Kelembagaan BKM telah mengangkat UP-UP salah satunya Unit Pengelola Keuangan tetapi Intensif UPK pun tidak jelas hanya dengan swadaya dan hal ini juga yang menjadikan alasan UPK sebelumnya mereka banyak yang mundur ataupun kurang aktif. Penagihan tunggakan selain dilakukan sendiri oleh petugas UPK sebenarnya telah dilakukan dengan membentuk tim khusus penagihan tunggakan dengan melibatkan pihak kelurahan,tokoh masyarakat tetapi tidak berjalan maksimal.Hal ini tidak sejalan dengan penelitian yang dilakukan oleh Purnomo (2015) yang menyatakan bahwa semakin tinggi kinerja BKM maka kinerja UPK semakin meningkat.

Berdasarkan hasil wawancara terhadap responden UPK Kota Kendari kelembagaan (BKM) masih kurang transparan kepda UPK untuk menyebarkan informasi terkait orangorang penunggak tahun tahun sebelumnya dan pengurus BKM sebelumnya banyak pelaku/peminjam dana bergulir atau peminjam itu masih keluarga dekatnya sehingga dana macet ini adalah warisan kepengurusan BKM sebelumnya sehingga agak kesulitan kami melakukan penagihan.

Secara umum tugas dan fungsi unit-unit pengelola kelembagaan (BKM) adalah menjalankan kebijakan-kebijakan yang diputuskan oleh BKM. Salah satu unit pengelola kegiatan kelembagaan BKM adalah Unit Pengelola Keuangan (UPK).Unit Pengelola Keuangan bertugas untuk mengelola dana pinjaman bergulir dan administrasi keuangan, baik yang berasal dari bantuan stimulan BLM PNPM maupun dari pihak-pihak lain seperti pemerintah, swasta, pihak ketiga yang memilki kepedulian terhadapmasyarakat miskin di Perkotaan (Chalia, 2015). Kegiatan pengelolaan kelembagaan (BKM) yang baik akan meningkatkan kinerja UPK PNPM Perkotaan Kota Kendari.

5. Pengaruh Pengawasan Pemerintah

Daerah Terhadap Kinerja Keuangan

Hasil analisis menunjukkan bahwa pengawasan pemerintah daerah berpengaruh positif dan signifikan terhadap kinerja keuangan UPK
PNPM Mandiri Kota Kendari.Hal ini menunjukkan bahwa pengawasan pemerintah daearah berpengaruh terhadap kinerja keuangan UPK PNPM Mandiri Kota Kendari.Koefisien jalur bertanda positif dan signifikan berarti ada hubungan searah antara pengawasan pemerintah daerah dan kinerja keuangan.Oleh karena itu dapat dijelaskan bahwa semakin tinggi tingkat pengawasan pemerintah daerah, maka semakin meningkat kinerja keuangan UPK PNPM Mandiri Kota Kendari.

Hal ini sejalan dengan penelitian yang dilakukan oleh Susanto dkk (2016) yang menyatakan bahwa terdapat pengaruh yang signifikan akuntanbilitas dan transparansi terhadap kinerja UPK. Pemerintah daerah melakukan pemantauan terhadap tugas dan tanggung jawab UPK serta pencapaian target yang telah dibebankan kepada UPK (realisasi vs target). Pengawasan yang dilakukan dengan baik (objektif, profesional, transparan, akuntabel, partisipatif, orientasi solusi, integrative dan berbasis kinerja) tentunya akan secara signifikan meningkatkan kinerja. Wasistiono, dkk (2009:143) menyatakan bahwa pengawasan adalah kegiatan untuk melakukan pengukuran dan tindakan atas kinerja dalam menyakinkan organisasi secara objektif dan merencanakan suatu cara dalan mencapai tujuan organisasi. Kontz (1996) menyatakan bahwa pengawasan dapat berjalan secara efektif memerlukan pengendalian yang baik yaitu harus disesuaikan dengan perencanaan dan kedudukan, bersifat objektif, mudah disesuaikan, sesuai suasanan organisasi, murah dan ekonomis, dan dapat mengasilkan tindakan korektif.

Hasil ini sejalan denganpenelitian Wawan (2009) yang mengemukakan bahwa pengawasan merupakan alat yang paling efektif yangdibangun ke dalam insfrastruktur organisasi dan menjadi bagian dari inti organisasi.Pengawasan yang terpadu akanmeningkatkan mutu dan insentif organisasi,menghindari biaya-biaya tidak perlu danmemungkinkan tanggapan yang cepatterhadap kondisi yang berubah-rubah. Hasil penelitian ini menunjukkan bahwa pengawasan yang dilakukan oleh pemerintah daerah terhadap kinerja keuangan UPK sudah cukup baik, sehingga kinerja akan terarah dan mencapai 
Jurnal Progres Ekonomi Pembangunan (JPEP)

Volume 4, Nomor 1 (2), Tahun 2019

http://ojs.uho.ac.id/index.php/JPEP

sasarannya. Selain itu penyimpangan danpenyelewengan juga akanterminimalisir kerena satuan kerjamenggunakan prosedur yangmerupakan bagian dari pengawasansebagai salah satu dasar pelaksanaankegiatan.

Hal ini sesuai denganpendapat Halim (2004) pengawasandapat membantu organisasidalam mencapai prestasi dan targetyang menguntungkan, dan mencegahkehilangan sumber daya, dapatmembantu menghasilkan laporankeuangan yang dapat dipercaya danjuga dapat memastikan suatuorganisasi mematuhi perundangundangan dan peraturan, terhindar darireputasi yang buruk san segala konsekuensinya. Selanjutnya dapatpula memmbantu mengarahkan suatuorganisasi untuk mencapai tujuannya, dan terhindar dari hal-hal yangmerugikan.

6. Peran Pengawasan Pemerintah Daerah sebagai Mediasi Antara Fasilitator Pendamping dan Kinerja Keuangan

Hasil pengujian mediasai dengan menggunakan rumus sobel bahwa pengawasan pemerintah daerah tidak dapat berperan sebagai mediasi pengaruh antara fasilitator pendamping dengan kinerja keuangan. Hasil ini dapat dibuktikan bahwa pengaruh variabel fasilitator pendamping terhadap kinerja keuangan pada model awal dengan melibatkan variabel mediasi pengawasan pemerintah daerah, menunjukkan fasilitator pendamping secara langsung tidak berpengaruh signifikan terhadap pengawasan pemerintah daerah dan secara langsung berpengaruh signifikan terhadapkinerja kinerja keuangan. Kemudian pengawsan pemerintah daerah juga berpengaruh signifikan terhadap kinerja keuangan. Hasil ini berarti hubungan antara fasilitator pendamping secara langsung dapat mempengaruhi kinerja keuangan, namun secara tidak langsung tidak dapat mempengaruhi kinerja keuangan jika dimediasi oleh pengawasan pemerintah daerah. Hasil pemeriksaan tersebut terdapat cukup bukti bahwa fasilitator pendamping tidak berpengaruh signifikan terhadap kinerja keuangan, yang di mediasi oleh pengawasan pemerintah daerah. Artinya pengawasan pemerintah daerah secara signifikan tidak dipengaruhi oleh fasilitator pendamping dan pengawasan pemerintah daerah secara signifikan mempengaruhi kinerja keuangan, kemudian fasilitator pendamnping secara signifikan mempengaruhi kinerja keuangan.

Dari hasil penelitian ini diketuahui bahwa pemerintah daerah tidak mampu memediasi fasilitator pendamping dalam meningkatkan kinerja keuangan UPK PNPM Mandiri Perkotaan. Hal ini disebabkan karena tidak adanya kerja sama yang baik antara pemerintah daerah setempat dalam hal ini kelurahan dan fasilitator pendamping dalam melakukan pengawasan atau pendampingan terhadap UPK PNPM Mandiri Perkotaan. Fakta dilapangan menunjukkan bahwa pemerintah daerah cenderung kurang melakukan pengawasan ataupun pendampingan terhadap kinerja UPK PNPM Mandiri Perkotaan.Pemerintah daerah menyerahkan sepenuhnya tugas pengawasan maupun pendampingan kepada fasilitator pendamping.Seharusnya sebagai pihak yang lebih mengetahui kondisi masyarakat yang terlibat dalam PNPM Mandiri Perkotaan, pemerintah daerah dalam hal ini keluarahan memiliki potensi yang lebih besar bersama fasilitator pendamping dalam meningkatkan kinerja keuangan UPK PNPM Mandiri Perkotaan.

7. Peran Pengawasan Pemerintah Daerah sebagai Mediasi Antara Kelembagaan dan Kinerja Keuangan

Hasil pengujian mediasai dengan menggunakan rumus sobel bahwa pengawasan pemerintah daerah dapat berperan sebagai mediasi pengaruh antara kelembagaan dengan kinerja keuangan. Hasil ini dapat dibuktikan bahwa pengaruh variabel kelembagaan terhadap kinerja keuangan pada model awal dengan melibatkan variabel mediasi pengawasan pemerintah daerah, menunjukkan kelembagaan secara langsung berpengaruh signifikan terhadap pengawasan pemerintah daerah dan secara langsung tidak berpengaruh signifikan terhadapkinerja kinerja keuangan. Kemudian pengawasan pemerintah daerah juga berpengaruh signifikan terhadap kinerja keuangan. Hasil ini berarti hubungan antara kelembagaan secara langsung tidak dapat mempengaruhi kinerja keuangan, namun secara tidak langsung dapat mempengaruhi kinerja keuangan jika dimediasi oleh pengawasan 
Jurnal Progres Ekonomi Pembangunan (JPEP)

Volume 4, Nomor 1 (2), Tahun 2019

http://ojs.uho.ac.id/index.php/JPEP

pemerintah daerah. Hasil pemeriksaan tersebut terdapat cukup bukti bahwa kelembagaan berpengaruh signifikan terhadap kinerja keuangan, yang di mediasi oleh pengawasan pemerintah daerah. Artinya pengawasan pemerintah daerah secara signifikan dipengaruhi oleh kelembagaan dan pengawasan pemerintah daerah secara signifikan mempengaruhi kinerja keuangan, kemudian kelembagaan secara signifikantidak mempengaruhi kinerja keuangan.

Dari hasil penelitian ini diketuahui bahwa pemerintah daerah mampu memediasi kelembagaan dalam meningkatkan kinerja keuangan UPK PNPM Mandiri Perkotaan. Hal ini disebabkan karena adanya kerja sama yang baik antara pemerintah daerah setempat yaitu kelurahan dan kelembagaan (BKM) dalam mendampingi UPK PNPM Mandiri Perkotaan untuk mengelola dana pinjaman bergulir yang bertujuan untuk meningkatkan penghasilan masyarakat miskin. Fakta dilapangan menunjukkan bahwa pemerintah daerah memberikan beberapa fasilitas kepada pihak BKM seperti mengadakan beberapa pelatihan kepada UPK seperti pelatihan aplikasi pembukuan UPK dengan menggunakan fasilitas kelurahan dengan tujuan untuk meningkatkan kinerja UPK PNPM Mandiri Perkotaan.

\section{KESIMPULAN}

Berdasarkan hasil penelitian, pembahasan dan interpretasi yang telah diuraikan pada bab sebelumnya dengan mengacu pada beberapa teori dan hasil penelitian sebelumnya, maka dapatlah ditarik beberapa kesimpulan sebagai berikut

1. Fasilitator pendamping berpengaruh negatif dan tidak signifikan terhadap pengawasan pemerintah daerah. Hal ini menunjukkan bahwa semakin tinggi kualitas fasilitator pendamping maka semakin rendah pengawasan pemerintah daerah.

2. Fasilitator pendamping berpengaruh positif dan signifikan terhadap kinerja keuangan UPK PNPM mandiri Kota Kendari. Hail ini menunjukkan bahwa semakin tinggi kualitas fasilitator pendamping makan semakin meningkat kinerja UPK PNPM Mandiri Kota Kendari.

3. Kelembagaan berpengaruh positif dan signifikan terhadap pengawasan pemerintah daerah. Hal ini menunjukkan bahwa bahwa semakin tinggi kualitas kelembagaan maka pengawasan pemerintah daerah semakin meningkat.

4. Kelembagaan berpengaruh positif dan tidak signifikan terhadap kinerja keuangan UPK PNPM mandiri Kota Kendari. Hal ini menunjukkan bahwa kelembagaan belum memberikan manfaat dalam meningkatkan kinerja keuangan UPK PNPM Mandiri Kota Kendari

5. Pengawasan penmerintah daerah berpengaruh positif dan signifikan terhadap kinerja keuangan UPK PNPM Mandiri Kota Kendari. Hal ini menunjukkan bahwa semakin tinggi tingkat pengawasan pemnerintah daerah maka semakin meningkat kinerja keuangan UPK PNPM Mandiri Kota Kendari.

6. Pengawasan pemerintah daerah tidak dapat berperan sebagai mediasi pengaruh antara fasilitator pendamping dengan kinerja keuangan UPK PNPM Mandiri Kota Kendari. Hal ini menunjukkan bahwa hubungan antara fasilitator pendamping secara langsung dapat mempengaruhi kinerja keuangan, namun secara tidak langsung tidak dapat mempengaruhi kinerja keuangan jika dimediasi oleh pengawasan pemerintah daerah.

7. Pengawasan pemerintah daerah dapat berperan sebagai mediasi pengaruh antara kelembagaan dengan kinerja keuangan UPK PNPM Mandiri Kota Kendari. Hal ini menunjukkan bahwa hubungan antara kelembagaan secara langsung tidak dapat mempengaruhi kinerja keuangan, namun secara tidak langsung dapat mempengaruhi kinerja keuangan jika dimediasi oleh pengawasan pemerintah daerah. 


\section{DAFTAR PUSTAKA}

Ardian, B. (2012). Peran Fasiliator Pembangunan. Urban Housing Specialist: PT. LPPSLH

Arifani, D.P. (2009). Peranan BKM dalam Menumbuhkan Kemandirian Masyarakat di Bidang Pembangunan Fisik Melalui P2KP Desa Sriwulan Kecamatan Sayung Kabupaten Demak.Skripsi. Semarang: Fakultas Ilmu Sosial.

Arsyad, L. (2008). Microfinance and Economic Development: Evidence From Developing Countries. Jurnal Ekonomi dan Bisnis Indonesia,

Askam, T. (2008).Pengaruh Pengawasan, Pemahaman SistemAkuntansi Keuangan dan Pengelolaan Keuangan Terhadap Kinerja SKPD Pemerintah Daerah. Jurnal Akuntansi Bisnis,

Berlo, D.K. (1961). The Process of Communication. New York: Holt, Rinehart, and Waston.

Chalia,N.A. (2015). Peran BKM dalam Penanggulangan Kemiskinan Berbasis Kemandirian di Desa Pecangaan Wetan Kecamatan Pecangaan Kabupaten Jepara.Skirpsi. Semarang: Fakultas Ilmu Sosial.

Dwiyarkasujana, P. (2011). Konsepsi dan Strategi PNPM Mandiri Perkotaan ke Depan. Karangayar: K P2KP Advanced.

Halim, Al. (2007). Akuntansi Sektor Publik Pengelolaan Keuangan Daerah, Edisi Ketiga. Jakarta: Salemba Empat.

Imila, B.A. (2014). Pengaruh LAR, BOPO, NPL, Jumlah KSM dan Fasilitator Lapangan Terhadap ROA pada Lembaga Keaungan Mikro Dalam PNPM Mandiri di Perdesaan Kabupaten Sidoarjo.Artikel Ilmiah. Surabaya: STIE Perbanas.

Jumingan.(2006). Analisis Laporan Keuangan, Cetakan Pertama. Jakarta: Bumi Aksara.

Koontz, H., Cyrill O.D,,\& Heinz, W.(1996). Essential of Management, Fourth Edition.New York - USA: McGraw-Hill Book.

Mardiasmo.(2002). Akuntansi Sektor Publik.Edisi 2.Yogyakarta: Penerbit Andi.
Purnomo, A.D. (2015). Analisis Kinerja UPK dan UPS dalam Penanggulangan Kemiskinan pada BKM Ngudi Makmur Desa Semanu Kecamatan Semanu Gunung Kidul.Skripsi. Yogyakarta: Fakultas Ekonomi.

Sekaran, U. (2010). Research Methods for BusinessFour Edition.Jakarta: Salemba Empat

Sumanta, J. (2005). Lingkar Kemiskinan di Indonesia. Jakarta: MPKP UI.

Susanto, I., Supranoto.,dan Hary Y. (2016). Akuntabilitas, Transparansi dan Kinerja UPK Kecamatan PNPM Mandiri Pedesaaan. Jurnal Ilmu Administrasi Negara.

Suyuti, H.M. (2012). Kontribusi PNPM Perkotaan Kurangi Kemiskinan di Kota Kendari. Kendari: Tribun Sultra.

Wasistiono, S., Nurdin, I., \&Fahrurozi, M. (2009).Perkembangan Organisasi Kecamatan Dari Masa Ke Masa. Bandung: Fokusmedia.

Wawan, S dan Anggarsari, L. (2009).Pengaruh Pengawasan Intern danPelaksanaan Sistem Akuntansi Keuangan Daerah Terhadap Kinerja Pemerintah Daerah.Jurnal Akuntansi Bisnis. 